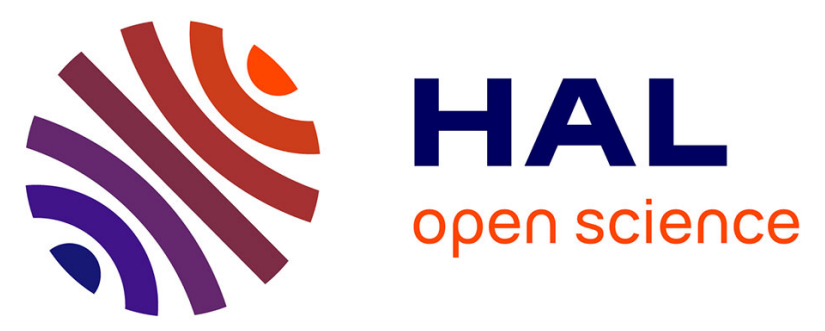

\title{
A novel pathway of soil organic matter formation by selective preservation of resistant straight-chain biopolymers: chemical and isotope evidence
}

Eric Lichtfouse, Claire Chenu, François Baudin, Claudette Leblond, Martine da Silva, Françoise Béhar, Sylvie Derenne, Claude Largeau, Patrick Wehrung,

Pierre Albrecht

\section{To cite this version:}

Eric Lichtfouse, Claire Chenu, François Baudin, Claudette Leblond, Martine da Silva, et al.. A novel pathway of soil organic matter formation by selective preservation of resistant straight-chain biopolymers: chemical and isotope evidence. Organic Geochemistry, 1998, 28 (6), pp.411-415. 10.1016/S0146-6380(98)00005-9 . hal-00193336

\section{HAL Id: hal-00193336 https://hal.science/hal-00193336}

Submitted on 3 Dec 2007

HAL is a multi-disciplinary open access archive for the deposit and dissemination of scientific research documents, whether they are published or not. The documents may come from teaching and research institutions in France or abroad, or from public or private research centers.
L'archive ouverte pluridisciplinaire HAL, est destinée au dépôt et à la diffusion de documents scientifiques de niveau recherche, publiés ou non, émanant des établissements d'enseignement et de recherche français ou étrangers, des laboratoires publics ou privés. 
Revised version

Organic Geochemistry 28, 411-415, 1998.

doi:10.1016/S0146-6380(98)00005-9

Correspondence: Dr. Eric Lichtfouse, INRA-CMSE-PME, 17, rue Sully, 21000 Dijon, France

Eric.Lichtfouse@dijon.inra.fr

\title{
A novel pathway of soil organic matter formation by selective preservation of resistant straight-chain biopolymers : chemical and isotope evidence
}

\author{
Éric LICHTFOUSE ${ }^{1 *}$, Claire CHENU ${ }^{2}$, François BAUDIN ${ }^{3}$, Claudette LEBLOND ${ }^{4}$, Martine Da SILVA ${ }^{4}$, \\ Françoise BEHAR ${ }^{4}$, Sylvie DERENNE ${ }^{5}$, Claude LARGEAU ${ }^{5}$, Patrick WEHRUNG ${ }^{6}$ and Pierre ALBRECHT ${ }^{6}$ \\ 1 Laboratoire Sols et Environnement, INRA/ENSAIA-INPL, BP 172, 54505 Vandoeuvre-lès-Nancy, France. \\ 2 Unité de Science du Sol, Institut National de la Recherche Agronomique, 78026 Versailles Cedex, France. \\ 3 Laboratoire de Stratigraphie, UMR CNRS 7573, Université Pierre et Marie Curie, 75252 Paris Cx 05, France. \\ 4 Institut Français du Pétrole, Géochimie, BP 311, 92506 Rueil-Malmaison, France. \\ 5 Laboratoire de Chimie Bioorganique et Organique Physique, URA CNRS 1381, ENSCP, 75231 Paris Cx 05. \\ 6 Laboratoire de Géochimie Organique, Université Louis Pasteur, 67008 Strasbourg Cedex, France.
}

\begin{abstract}
A resistant soil organic residue, 'humin', has been analysed by solid-state ${ }^{13} \mathrm{C}-\mathrm{NMR}$ and pyrolysis followed by molecular and ${ }^{13} \mathrm{C}$ determination of the pyrolysate alkane-alkene fraction. The results show the occurrence of highly aliphatic, straight-chain biopolymer material as a substantial part of soil organic matter. They confirm the hypothesis by which a part of soil organic matter can be formed by selective preservation of resistant highly aliphatic microbial polymers. This pathway comes in addition to the longstanding neogenesis hypothesis involving recondensation of small polar molecules such as amino acids, carbohydrates and phenols.
\end{abstract}

Keywords : ${ }^{13} \mathrm{C}$ of soil alkanes, NMR, resistant aliphatic biopolymer, pyrolysis of humin.

\section{INTRODUCTION}

Soil organic matter is composed of a complex mixture of living organisms, dead organic debris and anthropogenic inputs. During the decay of plants, a major part of plant carbon $(\sim 99 \%)$ is biodegraded and recycled to the atmosphere as $\mathrm{CO}_{2}$. The organic matter remaining in soils is thus a carbon pool exhibiting high resistance to biodegradation. Various but minor classes of soil organic molecules including lipids, amino acids, phenols, and carbohydrates have so far been identified (Schnitzer, 1991). Indeed, despite numerous investigations, the bulk of soil organic matter is made up partly of macromolecular, brown yellow humic substances whose molecular structure is still a matter of debate (Rice and MacCarthy, 1990, de Leeuw and Hatcher, 1992). Two main hypotheses have been advanced to explain how humification takes place : the selective preservation of plant biopolymers and the polycondensation of small molecules (Bollag and Loll, 1983). The selective preservation of plant biopolymer residues should favour the accumulation of ligno-protein nuclei in humic substances. Nonetheless, ${ }^{13} \mathrm{C}$ isotope studies of various soil organic pools show that such a process should play only a minor part in the formation of humus from crop soils (Lichtfouse et al., 1995). Therefore in situ processes are more likely to be involved :

* Author for correspondence 
1) the polycondensation (or neogenesis) pathway (Maillard, 1916, 1917), and 2) a pathway proposed by Lichtfouse et al. $(1995,1996)$ which involves selective preservation of resistant aliphatic biopolymers from microbes. While the polycondensation pathway is based upon polymerisation of rather small molecules such as amino acids, phenols, carbohydrates and various oligomers from biomass decomposition products as well as from root exudates, the new proposed pathway is based upon microbial biosynthesis of highly aliphatic cell walls which are chemically and physically resistant to biodegradation.

Several investigations have already detected the presence of aliphatic carbon in soils, including humic substances and resistant residues (Hatcher et al., 1981, Schulten H.-R. and Schnitzer, 1990, Kögel-Knabner et al., 1992, Beyer, 1996). In a recent investigation, Lichtfouse et al. (1995) proposed on ${ }^{13} \mathrm{C}$ isotope grounds that soil organic matter may additionally be stored by selective preservation of resistant biopolymers from soil microorganisms. Moreover, in a recent note, we identified resistant ultralaminae (Lichtfouse et al., 1996) which are structurally similar to those found in aquatic sediments (Largeau et al., 1990, Derenne et al., 1991), thus strengthening our view. Here, using molecular and isotope techniques, we show that a part of the resistant carbon in crop soil is indeed composed of saturated straight-chain hydrocarbons, and we discuss implications for organic matter preservation in soils.

\section{EXPERIMENTAL}

Detailed procedures are reported elsewhere (Lichtfouse et al., 1996) : a sample of maize crop soil $(290 \mathrm{~g})$ was thoroughly extracted with $\mathrm{CHCl}_{3}-\mathrm{MeOH} 3 / 1 \mathrm{v} / \mathrm{v}$ to remove free lipids, then with $\mathrm{NaOH} 0.1 \mathrm{M}$ to remove fulvic and humic acids. The remaining matter (humin and minerals) was treated with $\mathrm{HCl}$ and $\mathrm{HF}$, then extracted with $\mathrm{CHCl}_{3}-\mathrm{MeOH}$ to yield $3.9 \mathrm{~g}$ of solid residue $\left(31 \% \mathrm{C}, 3 \% \mathrm{H}, 2.5 \% \mathrm{~N}\right.$ and $40 \%$ of uncombusted matter). Solid state ${ }^{13} \mathrm{C}$ NMR spectra of the resistant residue were recorded on a Bruker MSL 400 spectrometer at $100.6 \mathrm{Mhz}$ for ${ }^{13} \mathrm{C}$ using the conventional Cross Polarization/Magic Angle Spinning (CP/MAS) technique with a contact time of $1 \mathrm{~ms}$, a pulse delay of $5 \mathrm{~s}$ and dipolar dephasing delays $\mathrm{T}_{\mathrm{DD}}$ of $0 \mu \mathrm{s}, 20 \mu \mathrm{s}$ and $40 \mu \mathrm{s}$. The residue was pyrolyzed for $5 \mathrm{~min}$ at $600^{\circ} \mathrm{C}$ in a gold tube under continuous argon flow. The pyrolysate was fractionated into alkane-alkene and aromatic fractions by silica gel column chromatography eluting with pentane then pentane/methylene chloride $(65 / 35 \mathrm{v} / \mathrm{v})$. The alkanealkene fraction was analysed using a HP 5890 gas chromatograph coupled to a VG Autospec mass spectrometer (GC-MS). Conditions : splitless injection; helium carrier gas; $60 \mathrm{~m} \mathrm{x} 0.2 \mathrm{~mm}$ capillary column coated with $0.2 \mu \mathrm{m}$ thickness methylpolysiloxane phase; oven temperature $50^{\circ} \mathrm{C}$ (1 min), $50^{\circ} \mathrm{C}$ to $140^{\circ} \mathrm{C}$ at $40^{\circ} / \mathrm{min}, 140^{\circ} \mathrm{C}$ to $320{ }^{\circ} \mathrm{C}$ at $2 \%$ min then isothermal $(60 \mathrm{~min})$; electronic ionisation $70 \mathrm{eV}, 31-650 \mathrm{amu}$ scan range. Isotopic analyses of individual $n$-alkanes from alkane-alkene fractions ( 3 to 4 replicates, deviation $\leq 0.3 \%$ ) were carried out under a continuous helium flow using a Hewlett Packard gas chromatograph coupled via a CuO furnace to a Finigan Mat 252 isotope ratio mass spectrometer. Isotope values were measured by comparison with $\mathrm{CO}_{2}, 5 \alpha$-androstane and $n$-tetracontane standards. Isotopic compositions are expressed in per mil as $\delta^{13} \mathrm{C}$ values relative to the Pee Dee Belemnite standard :

$\delta^{13} \mathrm{C}=\left[\left({ }^{13} \mathrm{C} /{ }^{12} \mathrm{Csample}-{ }^{13} \mathrm{C} /{ }^{12} \mathrm{Cstd}\right) /\left({ }^{13} \mathrm{C} /{ }^{12} \mathrm{Cstd}\right)\right] \times 10^{3}$ 


\section{RESULTS AND DISCUSSION}

A resistant organic residue was isolated from a maize crop soil by removal of lipids, humic acids, fulvic acids, and minerals. The solid state ${ }^{13} \mathrm{C}-\mathrm{NMR}$ of this residue exhibits a relatively high signal at $32 \mathrm{ppm}$ which shows the occurrence of aliphatic, saturated carbon (Fig. 1). The dephasing experiment shows a strong decrease in the $32 \mathrm{ppm}$ peak, which indicates that the saturated carbon is mainly composed of secondary $\left(\mathrm{R}^{-} \mathrm{CH}_{2}-\mathrm{R}^{\prime}\right)$ and tertiary carbon $(\mathrm{R}-\mathrm{CH}-$ $\mathrm{R}^{\prime} \mathrm{R}$ ') with few methyl groups (15 ppm) and few quaternary carbons. This finding suggests the occurrence of straight-chain skeletons with few branched and cyclic alkane skeletons, and is in agreement with IR analyses which give peaks at 2850 and $2920 \mathrm{~cm}^{-1}$ (unpublished data). The other main NMR peaks have been tentatively assigned to $\alpha$ carbons of $\mathrm{C}-\mathrm{O}$ or $\mathrm{C}-\mathrm{N}$ functions (56 $\mathrm{ppm})$, protonated $\mathrm{C}-\mathrm{O}$ or $\mathrm{C}-\mathrm{N}$ functions $(73 \mathrm{ppm})$, glycosidic $\mathrm{C}-\mathrm{O}(104 \mathrm{ppm})$, olefinic and/or aromatic $\mathrm{C}=\mathrm{C}(120 \mathrm{ppm})$, phenols (148 ppm), and quaternary ester or amide $\mathrm{C}(173 \mathrm{ppm})$.

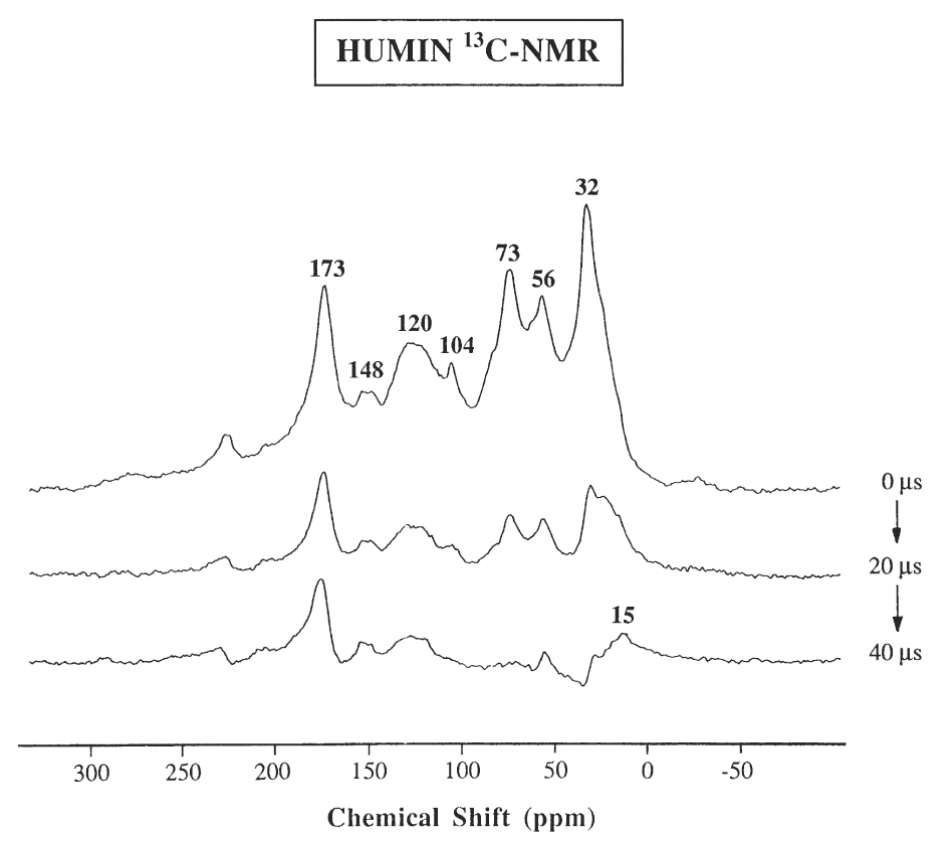

Figure 1. Solid-state ${ }^{13} \mathrm{C}-\mathrm{NMR}$ spectra of a resistant organic residue from a maize crop soil. Note the major peak at $32 \mathrm{ppm}$ showing the occurrence of saturated carbon. The dipolar dephasing experiments with delays of $20 \mu \mathrm{s}$ and 40 $\mu$ s show that this saturated carbon is mainly composed of secondary (R-CH2-R') and tertiary carbon (R-CH-R'R').

GC-MS analyses of the alkane-alkene fraction from the pyrolysate residue show a major contribution of linear alkanes and alk-1-enes along with very few branched and cyclic molecules (Figure 2). The hydrocarbons can be classified into two main categories. First, $n$-alkanes extending from $\mathrm{C}_{27}$ to $\mathrm{C}_{33}$ with a strong odd predominance, which are typical plant wax products (e.g. Lichtfouse et al., 1997). These alkanes have somehow been trapped in the organic network despite exhaustive $\mathrm{CHCl}_{3}-\mathrm{MeOH}$ extraction of the residue prior to pyrolysis. Nonetheless, this finding is in agreement with the occurrence of bonded alkanes and fatty acids in humic substances (Schnitzer and Neyroud, 1975), and further suggests that this physical mode of sequestration of apolar molecules may play a role in the preservation of soil organic matter. Second, $n$-alkane/n-alkene doublets extending from $\mathrm{C}_{10}$ to $\mathrm{C}_{25}$, are present with no odd/even predominance, which are 'true' cleavage products of the macromolecular soil matrix. Such a 
distribution, with very few branched and cyclic species is typical of kerogens and resistant aliphatic biopolymers (Behar et al., 1984, Derenne et al., 1988, 1991, 1992). Together with ${ }^{13} \mathrm{C}$ NMR data, these findings show clearly that a part of resistant organic matter from soil is made of straight-chain saturated hydrocarbons.

\section{HUMIN PYROLYSATE HYDROCARBONS}

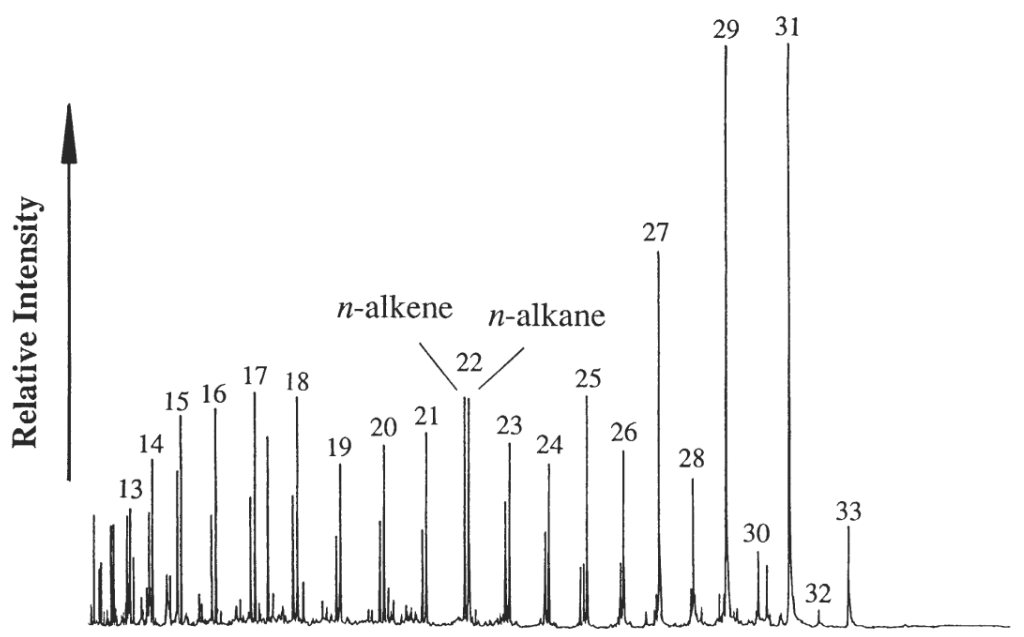

Time Direction

Figure 2. GC-MS total ion current of the alkane-alkene fraction of the soil organic residue pyrolysate. Note the occurrence of $\mathrm{C}_{10}-\mathrm{C}_{25}$ alkane-alkene doublets, typical of straight-chain macromolecular material.

The $\delta^{13} \mathrm{C}$ values of $n$-alkanes and $n$-alkenes from the soil residue pyrolysate are reported in Fig. 3 . The ${ }^{13} \mathrm{C}$-depleted values for the $\mathrm{C}_{29}$ and $\mathrm{C}_{31} n$-alkanes are in agreement with the derivation of these compounds from plant waxes of maize and wheat grown previously at the site (Lichtfouse, 1997). The $\mathrm{C}_{27} n$-alkane derives also from plant waxes, despite a ${ }^{13} \mathrm{C}$ enrichement which can be explained by a higher quantitative input of this molecule from maize waxes (Lichtfouse $e t$ al., 1994). In contrast, $C_{15}-C_{19} n$-alkenes are significantly enriched in ${ }^{13} \mathrm{C}$ relative to $n$-alkane homologues. Furthermore, the $\delta^{13} \mathrm{C}$ values of $\mathrm{C}_{15}-\mathrm{C}_{19} n$-alkenes are closer to the $\delta^{13} \mathrm{C}$ value of the total organic carbon. Such an isotopic feature gives two pieces of information. First, it shows that these cleavage products are more representative of the bulk carbon than the longer chain $n$ alkanes. Second, it indicates that the carbon source of the organisms synthesizing the $n$-alkene precursors is enriched in ${ }^{13} \mathrm{C}$. Therefore, this latter observation confirms our previous hypothesis on the formation of a substantial part of soil organic matter by 'preservation of resistant aliphatic biopolymers from microorganisms consuming ${ }^{13} \mathrm{C}$-enriched plant polysaccharides' (Lichtfouse et al., 1995). This novel, additional pathway contrasts with the current hypothesis involving recondensation of rather small molecules such as amino acids, phenols, carbohydrates and various oligomers. Nonetheless, a recent investigation on archaeological plant remains has brought some molecular evidence for the Maillard (or browning) reaction in buried organic matter (Evershed et al., 1997). Further work is now in progress to evaluate the significance of these two processes in various fossil material. 


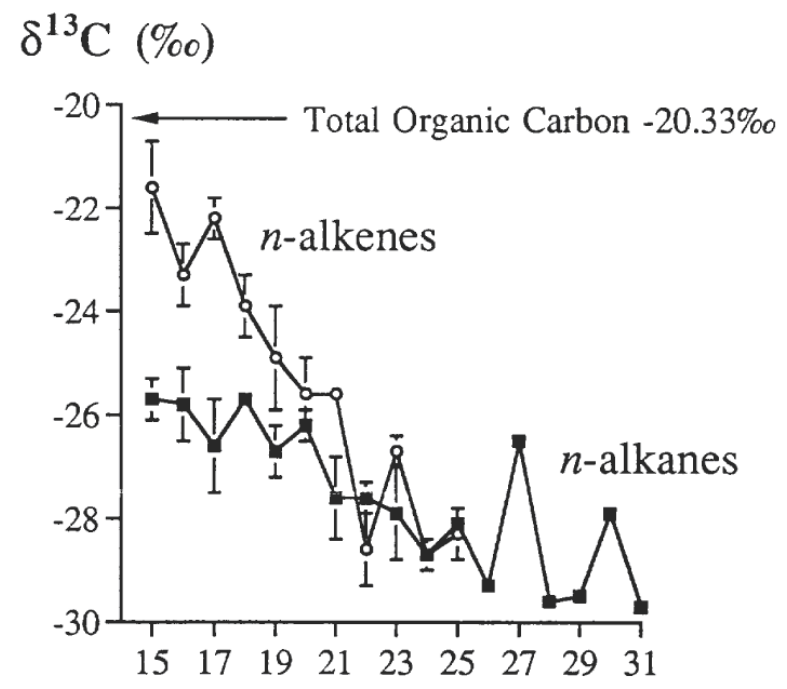

Carbon Number

Figure 3. $\delta^{13} \mathrm{C}$ values of $n$-alkanes and $n$-alkenes from the pyrolysate of a soil residue. Note the ${ }^{13} \mathrm{C}$ enrichment in the short-chain $n$-alkenes

\section{REFERENCES}

Behar F., Pelet R. and Roucache J. (1984) Geochemistry of asphaltenes. Organic Geochemistry 6, 587-595.

Beyer L. (1996) The chemical composition of soil organic matter in classical humic compound fractions and in bulk samples, a review. Zeitschrift für Pflanzenernährung und Bodenkunde 159, 527-539.

Bollag J.-M. and Loll M. J. (1983) Incorporation of xenobiotics into soil humus. Experientia 39, 1221-1231.

Derenne S., Largeau C., Casadevall E. and Connan J. (1988) Comparison of torbanites of various origins and evolutionary stages. Bacterial contribution to their formation. Cause of the lack of botryococcane in bitumens. Organic Geochemistry 12, 43-59.

Derenne S., Largeau C., Casadevall E., Berkaloff C. and Rousseau B. (1991) Chemical evidence of kerogen formation in source rocks and oil shales via selective preservation of thin resistant outer walls of microalgae : origin of ultralaminae. Geochimica et Cosmochimica Acta 55, 1041150 .

Derenne S., Metzger P., Largeau C., Van Bergen P. F., Gatellier J. P., Sinninghe Damsté J. S., De Leeuw J. W. and Berkaloff C. (1992) Similar morphological and chemical variations of Gloeocapsomorpha prisca in Ordivician sediments and cultured Botryococcus braunii as a response to changes in salinity. Organic Geochemistry 19, 299-313.

Evershed R. P., Bland H. E., van Bergen P. F., Carter J. F., Horton M. C. and Rowley-Conwy P. A. (1997) Volatile compounds in archaeological plant remains and the Maillard reaction during decay of organic matter. Science 278, 432-433. 
Hatcher P. G., Maciel G. E. and Dennis L. W. (1981) Aliphatic structure of humic acids; a clue to their origin. Organic Geochemistry 3, 43-48.

Kögel-Knabner I., De Leeuw J. W. and Hatcher P. G. (1992) Nature and distribution of alkyl carbon in forest soil profiles : implications for the origin and humification of aliphatic biomacromolecules. The Science of the Total Environment 117/118, 175-185.

Largeau C., Derenne S., Casadevall E., Berkaloff C., Corolleur M., Lugardon B., Raynaud J. F. and Connan J. (1990) Occurrence and origin of 'ultralaminar' structures in 'amorphous' kerogens of various source rocks and oil shales. Organic Geochemistry 16, 889-895.

de Leeuw J. W. and Hatcher P. G. (1992) Letter to the Editors, responding to A Chemical Structure for Humic Substances by H.-R. Schulten, B. Plage and M. Schnitzer.

Naturwissenschaften 79, 330-331.

Lichtfouse E. (1997) Heterogeneous turnover of molecular organic substances from crop soils as revealed by ${ }^{13} \mathrm{C}$ labeling at natural abundance with Zea mays. Naturwissenschaften 84, 23-25.

Lichtfouse E., Elbisser B., Balesdent J., Mariotti A. and Bardoux G. (1994) Isotope and molecular evidence for direct input of maize leaf wax $n$-alkanes into crop soils. Organic Geochemistry 22, 349-351.

Lichtfouse E., Dou S., Girardin C., Grably M., Balesdent J., Behar F. and Vandenbroucke M. (1995) Unexpected ${ }^{13} \mathrm{C}$-enrichment of organic components from wheat crop soils : evidence for the in situ origin of soil organic matter. Organic Geochemistry 23, 865-868.

Lichtfouse E., Chenu C. and Baudin F. (1996) Resistant ultralaminae in soils. Organic Geochemistry 25, 263-265.

Lichtfouse E., Bardoux G., Mariotti A., Balesdent J., Ballentine D. C. and Macko S. A. (1997) Molecular, ${ }^{13} \mathrm{C}$, and ${ }^{14} \mathrm{C}$ evidence for the allochthonous and ancient origin of $\mathrm{C}_{16}-\mathrm{C}_{18} n$-alkanes in modern soils. Geochimica et Cosmochimica Acta 61, 1891-1898.

Maillard L. C. (1916) Synthèse des matières humiques par action des acides aminés sur les sucres réducteurs. In Annales de Chimie, eds A. Haller and Ch. Moureu, Vol. V, pp. 258-317. Masson, Paris.

Maillard L. C. (1917) Identité des matières humiques de synthèse avec les matières humiques naturelles. In Annales de Chimie, eds A. Haller and Ch. Moureu, Vol. VII, pp. 113-152. Masson, Paris.

Rice J. A. and MacCarthy P. (1990) A model of humin. Environmental Science and Technology 24, 1875-1877.

Schnitzer M. (1991) Soil organic matter, the next 75 years. Soil Science 151, 41-58.

Schnitzer M. and Neyroud (1975) Alkanes and fatty acids in humic substances. Fuel 54, 17-19.

Schulten H.-R. and Schnitzer M. (1990) Aliphatics in soil organic matter in fine-clay fractions. Soil Science Society of America Journal 54, 98-105. 